\title{
Armenian Genocide Prerequisites in Travel Memoirs (With special reference to Noel Buxton and Harold Buxton's accounts)
}

\author{
Naira Gasparyan \\ Yerevan State University
}

\begin{abstract}
The findings of our linguocognitive research on a sound historical perspective establish a number of undeniable facts which will elucidate the situation of Armenians in Western Armenia in the pre-genocidal period.

The linguistic material of Noel and Harold Buxtons' accounts for the British Parliament, Travel and Politics in Armenial, published in 1914, has been studied with the application of a set of methods and approaches: the cognitive method of investigation combined with those of linguostylistic and linguocultural analyses on the extralinguistic basis and the method of purposive sampling. The book is an undeniable source of eyewitness facts which confirm the existing prerequisites for the 1915 Armenian genocide.
\end{abstract}

Key words: linguocognitive, eyewitness, prerequisites, Armenian genocide, travel memoirs.

\section{Introduction}

Remote areas have always been in the focus of travelers for diverse reasons. Apart from curiosity diplomacy, political pursuit, military campaigns, trade, business contacts, missionary activities, and the search for economic or educational opportunities were and still are the most common motives for foreign travel. Travel writing is a multidisciplinary genre. According to Faraz Anjum's standpoint it has developed a close relationship with history and colonialism. Anjum (2014:191-205) writes in his article that different academic disciplines have employed travel for different reasons. All those scholars who are working 
on colonialism, race, and cultural relations have "rediscovered those travel narratives that accompanied, described, extended, even made possible, the expansion of capital and colonialism. " Anjum's research, is enormously valuable, since he made an effort to present a thorough study of this genre and its generic features. He discusses Jan Borm's approach towards travel writing who shares Jonathan Raban's standpoint on the definition of the genre which defined figuratively, as a literary form, is a "notoriously raffish open house where different genres are likely to end up in the same bed. It accommodates the private diary, the essay, the short story, the prose poem, the rough note and polished table talk with indiscriminate hospitality. It freely mixes narrative and discursive writing". Anjum then cites Jean Roudaut, a French author to explain that it is discontinuous and thus "juxtaposes also segments of texts which differ in tone... The text is stratified: it consists of various layers of voices, vocabulary (the descriptions vary in kind: landscapes, habitats, clothing, works) and style... The travel book combines the heterogeneous (using all in one the form of memoir, diary and the letter) and disparity. It aims at the mosaic”. Anjum concludes that although, many scholars, like Tim Youngs, have tried to put it in some framework, its definition is an impossible task ${ }^{2}$ (Anjum 2014:191-205).

The Value of the Buxtons' Travel Memoirs in Establishing the Pre-Genocidal Eight Stages

In 1800-1900 the British government, with imperialistic intentions, developed a desire to learn everything about Armenians who lived partially separated between Turkey and Russia. The authors of the book, British noblemen and politicians, travelled in Western and Eastern Armenia in the autumn of 1913, just before the Genocide of 1915, and at the end of their journey presented a relatively minute investigation of the Armenian national identity and demeanour. To make their accounts sound as trustworthy as possible, they included in the second part of the accounts Aram Raffi's discussions of historical facts dating back to various periods of Armenian history, and Raffi's own observations of Armenian national values and identity. Thus, in 1914 the accounts for the British Parliament were published. Noel and 
Harold Buxtons were sure that such piece of factive writing in the form of a book, reachable to the average English person irrespective of their educational level, was urgent and greatly demanded since the international community did not have any proper idea of the true Armenian identity and Armenian problems.

Travel memoirs of the period of 1830-1916, authored by Europeans and Americans, have a very specific value for establishing important facts and events which are often denied by the colonizers generally, and by the Turkish government and modern Turkish historians, particularly. And, thus, they form an interesting area for those investigators who appear to be involved in Armenian and Genocide Studies. The most significant merit of this travel memoir book is that it focuses the reader's attention on the prerequisites of the 1915 Turkish Genocide of the Armenians. The eye-witnessed reality depicted by the Buxtons in Travel And Politics in Armenia, actually corresponds to the 8 pre-genocide stages formulated by Gregory Stanton, the president of Genocide Watch, in a briefing paper called The 8 Stages of Genocide at the United States Department of State in 1996 (www.genocidewatch.org/images/8StagesBriefingpaper.pdf)

Below are Noel and Harold Buxtons observation presented in Travel And Politics in Armenia adjusted to Stanton's theory of the 8 stages of the pregenocidal period:

1. classification - The Turks and Armenians are viewed as opposing antagonistic forces;

2. symbolization - Christian Armenians are referred to by the Turks as infidel giaours;

3. discrimination - Armenians in Armenia were deprived of any human rights at all while dominant Turks used law, custom, and political power to deny the rights of the "inferior" Armenians although, as many sources confirm, the Buxtons among them, on the eve of the WWI Turkish artillery ${ }^{3}$ was trusted to Armenians;

4. dehumanization - giaour and infidel Armenians were treated by the Turks as second-class citizens, and were later declared prisoners which was a 
synonym to enemies of the state ... Hatred, humiliation, torture and all kinds of and physical abuse was part of Armenian everyday life;

5. organization - like all other genocides, the Armenian genocide of 1915 and all the pre-genocide massacres made the Buxtons think that Armenians should be rescued from the Turks. The Buxtons highlight that there are no massacres in Turkey except when ordered by the Government (Buxton \& Buxton 1914:43);

6. polarization - hate groups, according to Stanton, broadcast propaganda that reinforces prejudice and hate, moderate leaders are those best able to prevent genocide and they are often the first to be assassinated, antagonism cannot be negotiated because of mass killings and massacres... The Buxtons discussed in their accounts all these characteristics of polarization they eyewitnessed. Not able to change anything, they damned the Turks;

7. preparation - euphemisms like ethnic cleansing, deportation (Gasparyan 2016:146-147) were used, addresses of Armenians were fixed by the authorities, lists of the victims were made beforehand, armies were built and weapons bought. Massacres were seen by the Turkish government as the sole solution to the Armenian question;

8. persecution - Armenian victims on ethnic, national, religious basis were segregated and confined to a famine-struck regions where they starved if not killed.

All the genocides prove to have denial as their final stage (Rummel 1997:367). Turks, the organizers of 1915 Armenian Genocide, take an effort to explain and justify what happened confining their deeds to the ongoing war WWI. Another justification is promoted with the cold-hearted use of the euphemism demographic engineering (Şeker 2013).

The predictions of the approaching genocide made by the Buxtons were shared by other outstanding public figures as well. Taner Acçam's $\boldsymbol{A}$ Shameful $A c t^{4}$ (Acçam 2006), makes the link between Gallipoli and the initiation of the Armenian Genocide even more explicit. The stylistically singled out sentence " $A$ nation that feels itself on the verge of destruction will not hesitate to destroy another group it holds responsible for its situation" provides solemn ground for the Turkish implicit fear. 
"Almost everyone believed that the capture of Istanbul was only a question of time... It was not a coincidence that the Armenian genocide took place soon after the Sarikamis disaster and was contemporaneous with the empire's struggle at Gallipoli... $A$ nation that feels itself on the verge of destruction will not hesitate to destroy another group it holds responsible for its situation... A prediction made by the German Ambassador Wangenheim is worth mentioning. With the outbreak of the war in August 1914, Henry Morgenthau, the US ambassador, warned him that the Turks would massacre the Armenians in Anatolia, to which Wangenheim replied, "So long as England does not attack Cannakale, the Turkish fortress at the Dardanelles, there is nothing to fear. Otherwise, nothing can be guaranteed.

This simple piece of fact dating to August 1914 is another prediction that the Turks would massacre the Armenians in Anatolia, and T. Acçam sorrowfully mentions: "However, this is precisely what happened."

Robert Manne cites Taner Akçam, whose analysis of the mechanics of the genocide is the most convincing and who believes the fundamental decision to unleash the deportations and the massacres of the Armenians was taken during meetings of the central committee of the Young Turks' party, the Committee of Union and Progress, in March 1915, at the time of the beginning of the Dardanelles naval campaign. "The main engineer of the Armenian Genocide was Dr. Bahettin Shakir, who had convinced the CUP leadership that at the same time of crisis for the empire, the "internal" enemy, the Armenian, was as dangerous as the "external" - the Russian, the Brittish, the French." Making Trouble: Essays Against the New Australian Complacency (Manne 2011:315-316).

Donald Bloxham, a professor of Modern History, specialising in genocide, war crimes and other mass atrocities studies, writes in The Great Game of Genocide, (Bloxham 2005) that the arrests of the Armenian intelligentsia on 24 April 1915 were triggered by the news that the Brittish and the French were about to land their troops at Gallipoli. For the first time Turkey's inhuman policy against 
Armenians was viewed by European superpowers Britain, France and Russia as "crime against humanity and civilization", Bloxham mentions. In the introduction, Bloxham provides an overview of both the CUP's decisive role as perpetrators and the role of Western powers in the Armenian genocide and the later politics of denial. According to G. Stanton's theory, genocides do not appear without prerequisites and thorough preparations. Noel and Harold Buxtons being eyewitnesses of Turkish atrocities in Armenia laid down their observations mentioning several very important factors and facts, among them - Armenians were reduced to a minority as a result of the steady policy conducted by Abdul Hamid II and the Turkish government (Buxton \& Buxton 1914:131). According to the Buxtons it was quite Turkish to seriously consider the policy of general massacre when solving national issues like Sultan Abdul Mejid did once when he had to settle the Kurd question (Buxton \& Buxton 1914:19). Buxtons reveal that Abdul Hamid ordered the massacres as a deliberate method of reducing the Armenians to mental and numerical weakness (Buxton \& Buxton 1914:127). Concerning 1909 massacres we find echoes in Times cited and elucidated by Varoujean Poghosyan. From the issue of April 23, 1909 we learn that The Turquie announces a massacre of Christians at Antioch by criminals escaped from the Payas prison near Alexandretta (Poghosyan 2014:164), while Buxtons speak about a deliberate release of criminals who would help the Turkish authorities to solve the Armenian question.

The Buxtons were very much concerned about the fate of Armenians who were on the verge of extinction by the Turks. The display of the 1915 genocide prerequisites in the book recently captured the attention of scholarly people. In 2014 D. Mayersen laid down her observations of the Rwandan and Armenian genocides reviewing the prerequisites of the both - she concludes that both were predictable. To investigate the Armenian genocide prerequisites she had studied Travel and Politics in Armenia by Noel Buxton and Harold Buxton (Mayersen 2014). Even if there were no other documents, no press releases, studies, survivors' and eye-witness stories, the Buxtons' accounts for the British Parliament in a rather trustworthy way predict that the Armenians were going to face a tragedy of genocide without failure. 
Let us adduce the passage from their accounts which explains the whole situation:

In view of all this, their grievance is too great to be tolerated, or its settlement postponed to the season convenient for Europe. It is both cultural and economic, but above all it is one of personal and moral insecurity. A people of this kind, not ordinary but highly gifted, are artificially subjected to a system unfitted even for the government of savages. 'Lesser breeds', as Kipling called them, are sometimes regarded as beings whose disappearance does not matter, unless they increase our dividends by their labour. Civilised peoples are viewed as having an importance in themselves, and also (as commercial markets) to other races of men. But a third class is recognized - the few nations who make a contribution to the arts and culture, which the world cannot afford to lose. What is not sufficiently recognised is that to this small class belongs the Armenian race. The solution, by Turkish reform from within, must be discarded, judiciously but absolutely. The evidence is final and (in the fullest sense) damning.

(Buxton \& Buxton 1914:122)

Buxtons make it quite obvious that civilized Europeans do not realize that something must be done to rescue Armenians who make a contribution to the arts and culture. The world cannot afford to lose them. The self-explanatory message does not need any further clarification, Armenians are on the verge of total extermination. The Buxtons' travel accounts as sources of history are very unique and of undeniably significant value.

\section{Conclusion}

The research establishes that travel memoirs and accounts of the pre-genocidal period presented by outstanding public figures are of significant value since they contain the prerequisites of the 1915 Turkish genocide of the Armenians. The Buxtons clearly saw the upcoming global disaster - the genocide. The British 
humanists published their accounts hastily and without editing. The wanted to attract the British and European attention on vital Armenian issues.

\section{Notes and References:}

1. For our research we have used the 1914 version of the accounts available at: $<$ https://archive.org/details/travelpoliticsin00noel> [Accessed January 2015]. The book Travel and Politics In Armenia, is republished from time to time. For analysis and discussion also for translation of passages we referred to the first part presented by Noel Buxton and Harold Buxton, although the second part authored by Aram Raffi, the son of famous Armenian writer, can be of much interest for those who investigate or are carried away by Armenian identity issues.

2. To define the literary genre of travel memoirs Anjum Faraz refers to Jan Borm's, Jonathan Raban's, Jean Roudaut's Tim Youngs's considerations of the definition of the genre. (Jonathan Raban, For Love and Money: Writing-ReadingTravelling 1968-1987 (London: Picador, 1988); Jan Borm. (2004) Defining Travel: On the Travel Book, Travel Writing and Terminology, Jean Roudaut, La litterature et le voyage, le magazine du Centre 94 (Paris: Centre Georges Pompidous, July/August 1996); Tim Youngs Travellers in Africa: British Travelogues, 1850-1900 (Manchester: Manchester University Press, 1994), 8.

3. On the eve of the WWI Turkish artillery was trusted to Armenians who in the battle of Gallipoli, April 25 1915, proved to be courageous professionals, got medals from Enver Pasha, but later were declared to have fabricated their stories and were massacred together with their families.

4. Taner Akçam peremptorily writes that the title of his book $A$ Shameful Act is a quotation from a speech on Armenian genocide delivered by Mustafa Kemal Atatürk at a session of the Grand National Assembly of Turkey on 24 April 1920 (Taner 2006:12-13, 335-336, 348).The choice of title no doubt reflects the author's desire to give indication of the contents of his work. Yet the above words were not actually used by the founder and the first president of the 
Turkish republic with regard to the Armenian relocations of 1915, but pronounced pertaining to the claims of the Allied powers on these events. (Taner 2006:464). The author makes effusive acknowledgment in the text and in various endnotes of the help he received from Vahakn Dadrian, Peter Gleichmann and the Zoryan Institute for Contemporary Armenian Research and Documentation (see, for instance, Taner 2006:465). Even without this explicit acknowledgment his debt to these various individuals and agencies is patent throughout much of his book and especially in the opinions he offers.

\section{Sources of Data:}

1. Akçam, T. (2006) A Shameful Act: The Armenian Genocide and the Question of Turkish Responsibility. New York: Metropolitan Books/Henry Holt \& Company. Available at: <www.mfa.gov.tr/data/DISPOLITIKA/2016/ 16_-yucel-guclu_-a-shameful-act.pdf> [Accessed October 2017].

2. Anjum, F. (2014) Travel Writing, History and Colonialism: An Analytical Study // JRSP, Vol. 51, No. 2, July-December, pp. 191-205.

3. Bloxham, D. (2005) The Great Game of Genocide: Imperialism, Nationalism, and the Destruction of the Ottoman Armenians. New York: OUP.

4. Buxton, N. MP and The Rev. Buxton, H. (1914)Travel and Politics in Armenia, London: Smith Elder \&CO.

5. Gasparyan, N. (2016) Analysis and Interpretation of Genocide Related Terms. // Armenian Folia Anglistika, International Journal of English Studies, 2(16). Yerevan: YSU Press.

6. Manne, R. (2011) Making Trouble: Essays Against the New Australian Complacency, Melbourne: Black Inc. Available at: <https://books.google.am/ books?is bn $=1921870222>$ [Accessed September 2017].

7. Mayersen, D. (2014) On the Path to Genocide: Armenia and Rwanda Reexamined, New York: Berghahn books.

8. Poghosyan, V. (2014) The Echoes of the Armenian Massacres of Cilicia in "The Times". // Armenological Issues, Bulletin 1, pp.159-164, Yerevan: YSU Press. 
9. Rummel, R. (1997) Statistics of Democide. Charlottesville. // Available at: $<$ https:// www.hawaii.edu/powerkills/GENOCIDE.HTM> [Accessed March 2016].

10. Stanton, G. President, Genocide Watch, The Ten Stages of Genocide. Available

at: $<$ www.genocidewatch.org $>,<w w w$. genocidewatch.org/images/8StagesBrie fingpaper.pdf $>$ [Accessed May 2017].

11. Şeker, N. (2013) Forced Population Movements in the Ottoman Empire and the Early Turkish Republic: An Attempt at Reassessment through Demographic Engineering // EJTS,16. Available at: <https://ejts.revues.org/439> [Accessed March 2017].

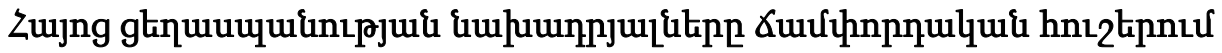

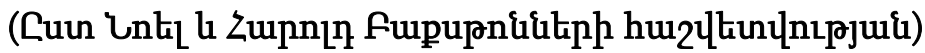

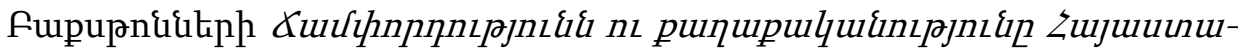

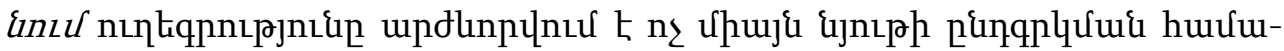

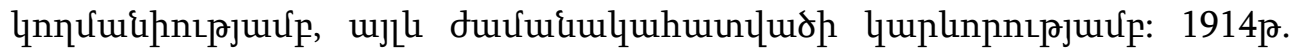

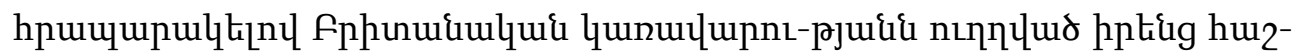

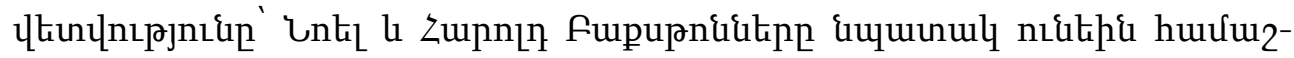

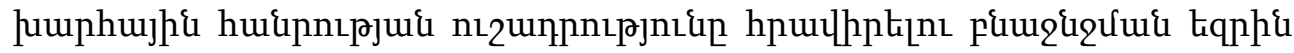

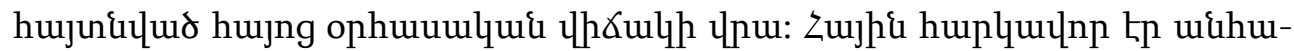

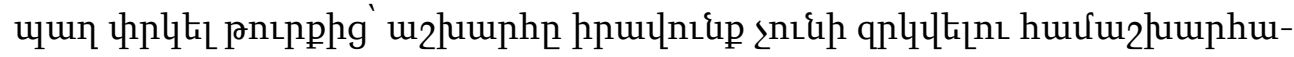

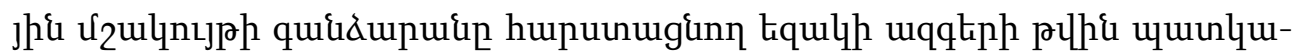

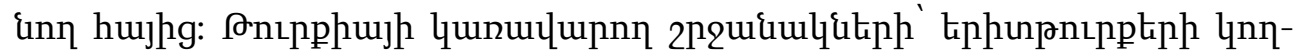

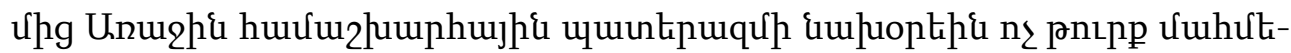

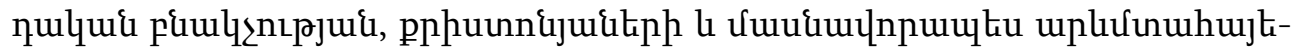

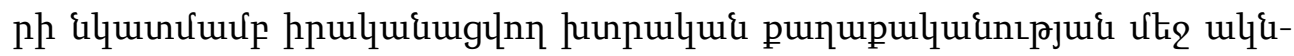

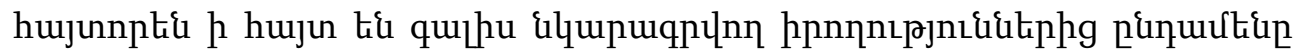

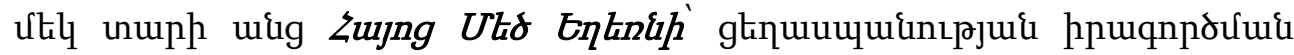

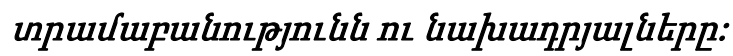

